\title{
Study on the Translation of Tourist Public Signs from the Perspective of Ecological Translation
}

\author{
Yayan $\mathrm{Yu}$ \\ Shanxi Normal University, China
}

\begin{abstract}
With the accelerating process of internationalization, China and the world become more and more inseparable. There are a growing number of foreigners coming to China for work and travel. Therefore, the translation of public signs is particularly important. It not only brings convenience to the tourists in China, but also helps to raise china's image as a great power.

Public signs are a special applied literary form, which is an important part of social terms. Its social functions are self-evident. Generally speaking, Public signs are the written and graphic information that can guide people's behavior and is featured by indication, prompt, constraint and coerciveness.

As a new mode of research, eco-translatology tries to depict and interpret the process of translation from the perspective of ecology, which is also the feature that eco-translatology differentiates it from the previous studies. Through combining the translation with its surrounding environment, readers can get a better understandable version. This paper employs the method of case study. By analyzing the errors existing in public sign translation, the author gives a better solution under the guidance of eco-translatology.
\end{abstract}

Index Terms - eco-translatology, tourism, public sign

\section{INTRODUCTION}

\section{A. Purpose of the Research}

With the high-speed growth of China's economy, China's international status has increased remarkably, and China is playing an increasingly important role in resolving international affairs. Therefore, there's a growing need for people from other countries to get acquaintance with China. During this process, international communication plays a critical role in achieving this goal.

However, the present situation is not very pleasant. There are a large number of errors existing in the Chinese-English translation that will make it hard to understand. For example, maybe you can see the public signs like "open water room" in the hospital, mall or somewhere in the public. What will come into your mind when you see it at first sight? Can you figure out that the signs are trying to tell you that you can fetch a cup of hot water from here? Maybe you can make sense of it by translating it with your Chinese thinking, but what about foreigners? Obviously, they will be confused about such signs.

In light of the condition of the translation of tourist public sign, the author of this paper attempts to analyze it under the guidance of eco-translatology, in a move to improve the quality of translation.

\section{B. Significance of the Research}

Under the guidance of the eco-translatology, this paper aims to find out a more effective and accurate translation strategy of tourist public signs. Its significance is mainly reflected in the following three aspects:

Firstly, theoretical significance. This paper introduces the concept of eco-translatology by combining it with the translation of tourist public signs, thus providing a new vision for the translation of public signs on scenic spots.

Secondly, practical significance. Based on the eco-translatology, this paper discusses the strategies employed in the translation of tourist public signs, which can be helpful for translators to get a better understanding of the translation, thus yielding a standard translation version of tourist public signs.

Thirdly, social significance. The research can draw the attention of the relevant departments to the working of translation, making them strengthen their supervision over it, and eventually generating positive social utilities, such as creating a sound language atmosphere and enhancing our national image and so on.

\section{Research Methods}

In order to get as many samples as possible, the author of this paper visited a lot of places of interest and took them down by taking photos of the public signs. This is the major source of collecting data. Besides, the author also looked through a large number of related books, magazines, and newspapers, and searched the internet for useful information. After that, the author analyzed the samples at length and gave suggestions about how to revise them under the guidance of related theories and strategies.

D. Organization of the Research

This paper consists of six parts, named introduction, literature review, theoretical foundation, the translation of tourist 
public signs, the translation strategy under the guidance of eco-translatology and conclusion. Each part studies a particular aspect of the research. The details of the organization are as follows:

In the first part, the author gives a general introduction of this paper, including the purpose, the significance, the methods used in the research and the organization of this paper. The goal of this research is to improve the quality of translation of tourist public signs with eco-translatology as the guidance. The significance of the study is to yield a better translation version of tourist public signs so as to better serve friends from other countries. The methods of collecting information are given to let readers know where the data come from.

Part 2 is the literature review, which gives the research status of the translation of tourist public signs from the perspective of home and abroad, and the shortcoming of current research.

Part 3 talks about something about the eco-translatology and tourist public signs. Firstly, the author gives the background and main contents of eco-translatology. Secondly, the author introduces the definition, features and functions of the tourist public signs, giving readers a general idea of tourist public signs.

Part 4 is an important part in this paper. The author lists some examples of tourist public signs and analyzes the errors made in the translation, which are misuses of linguistic knowledge and those caused by misunderstanding to cultures and context.

Part 5 gives the solutions and strategies under the guidance of eco-translatology on the basis of part 4. The solutions are given from three different angles, from the translators, the public and the government. And then is the concluding part. It makes a brief review and concludes the whole paper with its limitations.

\section{LITERATURE REVIEW}

\section{A. The Research Status of the Translation of Tourist Public Signs}

\section{Overseas Research Status}

The researches about public signs translation began with the publishment of "comparative stylistics" in 1959. Mary Snell-Hornby conducted an empirical research to the public signs collected from the countries where take English and Germany as mother language. She thought that translating public signs need to take different techniques according to the contexts, because public signs translation is a cross cultural activity, the tremendous difference between different culture is a very important factor. (Snell-Hornby, 2001) After analyzed and studied more than 200 public sig 1 ns used in real life, he thought that in English and Germany, different techniques and strategies, different grammar structures and verb conjugations were used in public signs translation. And both of the languages expressed imperative meaning in declarative sentence instead of prohibition.

New mark talked about the issue with functional linguistics theory. According to these functions, new mark put forward corresponding translation method. He thought that functional linguistics theory is a language function theory that can be applied in translation most effectively. Specially, he pointed out that vocative function is means to make receivers show certain responses or reflections in parole or some kind of non-linguistic communicative symbols. From the analysis of New Mark we can know that the method of equivalence principle and communicative translation should be adopted when translators translating signs or other vocative texts.

Totally speaking, the foreign research of public sign translation mainly from the perspective of so called linguistic landscape, which was defined as "the visibility of language of public and commercial signs in a given territory" and more precisely "the language of public road signs, advertising billboards, street names, place names, commercial shop signs, and public signs on government buildings which combine to form the linguistic landscape of a given territory, region, or urban agglomeration." (Sr.Anwar AL-thway, 2008). Their views laid particular emphasis on the research of linguistic techniques and strategies in multilingual environment and the discussion of broad culturology in the contexts of social linguistics. (Cenoz, J \& Gorter, D, 2006) Meanwhile, it was commonly accepted that there are two basic functions: the one is informational function, the other is symbolic function. (Landry, R \& Bourhis, R, 1997)

2 Domestic Research Status

The research of public signs translation attracted domestic researchers' attentions originally from 1990s, after that it developed fast. The author searched in the document library of National Knowledge Infrastructure, CNKI for short, with the entry of public sign. Altogether 661 related articles or papers could be found, the time ranged from 2001 to 2011. Something need our notice was there were 236 articles between 2001 and 2008, the rest were published from 2008 to now. From this we can catch a glimpse of the increasingly developed attention to the public signs translation, even not so completely demonstrated. This paper divided the researching achievements of public signs translation of china since 1990s into three parts and states as follow:

1990s-2000s, in the year of 1990, the fifth issue of Chinese translation published Duan liancheng's article, which pointed out the translation errors in some resorts and hotels, this article limited in the discussion of correction (Duan liancheng, 1900). In 1998 the second issue of Shanghai science translation, Ni Chuanbin and Liu Zhi (1998) put forward five principles in public signs translation in their paper, they were "brief, easily understandable, proper tone, standardization and medium humor". (p. 46). These can be considered as a try of theoretical research to public signs translation. But in terms of practice, the proper tone and medium humor were not so easy to define and grasp. In this period, for the reason that the research of public signs translation just begun, and on the other hand, the problems of the 
using of public signs translation were not so prominent and have not yet drawn enough attention from translational circle. Most of the researches to public signs were focus on finding errors and then corrected them.

With the policy of reform and opening up going forward continuously, the communication between China and outside world strengthened very much, the problems caused by improper using of public signs translation attracted more and more attentions. Accordingly, related researches soared in this period. Some institutes even set up special organizations to charge these researches, such as the Public Signs Translation Centre set up by Beijing international studies university. In this period, researchers deepened and broadened their studies very much from many aspects, tried to analyze the issue of public signs translation with different theoretical frameworks.

At present, the domestic researchers are trying to study the public translation from different angles and perspectives with various kinds of main translating theories. Totally speaking, the mainly used theories in the research of public signs translation are follows:

Germany Functionalistic Theories, this translating theory paid attentions to the function of translated texts and the comprehensive effects of the environment, receivers and media. Emphasizing the destination of translated texts is realizing the expected functions. Germany researcher Reiss divided texts into three kinds on this basis, they were text emphasizing context, emphasizing form and emphasizing the influence to receivers. He thought that the text type decided the translating strategies. In the opinion of the communicative translation theory of new mark, a translator should make the effects the translated texts to the readers of target languages or the information provided by the translated text equal to that brought by the original languages to the readers of original languages and original texts as close as possible. Yi ruixian (2010) discussed the translating strategies of public signs translation from the perspective of German function school. Wang Yingcai (2009) discussed the languages, cultures and emotions to readers considered in the process of public signs translation with the views of communicative translation theory. Guo Xiaodan (2011) discussed how to reflect the communicative strategies of original language in the target language under the theory of communicative translation theory. She thought that when translating the public signs, a translator should know well the linguistic characteristics and functional meaning of the public signs, have a knowledge of the distinction between different cultures. Beyond these classic translatology theories, many researchers also made full use of other perspectives to carry out new explorations. For instance, Hou xiaojing (2011) discussed from the perspective of principle of politeness. These efforts showed the diversity of the research of public signs translation.

It is now not very popular in researching the public signs translation from the perspective of inter discipline. And this is a valuable direction worth exploring.

3 The Research Status of Public Signs: Translation from the Perspective of Eco-translatology

The research of public signs translation has already undergone a comparatively long period of development. As mentioned above, many translating theories that have developed to mature have been used to indicating the researches of the public signs translation. However, the Eco-translatology is a translatology theory developed and improved in recent years. Though the theory itself needs further improvement, it is drawing an increasing attention. Many pioneers have paid their attention to or even took the advantage of the Eco-translatology to discuss the issue about the public signs translation. This paper discussed the feasibility and operability of researching the public signs translation from the perspective of Eco-translatology with the method of theory analysis and empirical research. Shu huijuan (2010) interpreted the theme slogans translation of Shanghai World Expo with the "three dimensions" principle in Eco-translatology. In addition to the discovery of new researching issues and new researching perspectives, the researching emphasis in the future will be focused on the integration of "basic theory research, applied translation studies and the terminology." The final destination is the establishment of theory system the public signs translation, this need researchers continue to increase the depth and breadth of research.

\section{B. The Shortcoming of Current Research}

There are over 20 years since the study of public signs translation begun in 1999s, in this period many researchers obtained many delectable achievements, while, for the reason of a new arrival the China is, it is inevitable that different shortcomings emerged. Not a few researches used the examples and samples that have been very frequently used before, many researching angles repeated and overlapped. Lacking of pioneering and creative consciousness, Concluded as follows:

Repeated researches took a large part of the whole researching achievements. Throughout the researches to the public signs translation recent years, the author found that the phenomenon of repeating is very common. Most were about such as the function and scope of the public signs, the linguistic and cultural characteristics of the public signs, corrections and descriptions to the error types of the public signs.

The samples of the public sign are commonplace used in many articles frequently. For instance, “注意台阶”, “小心 火烛”, “入口”, “严禁吸烟” no more new sign samples. Or the study just stayed on the surface, no deeper exploration.

The researches with various theories put most efforts on interpretation and prescription, and all of these directive theories were effective in certain degree. But more or less, have different weakness in explanatory power.

\section{THEORETICAL FoundATION}

\section{A. The Background and Main Concepts of Eco-translatology}


1 The Background of Eco-translatology

Eco-translatology, which analyzes and interprets the translation under the guidance of ecology, was put forward by professor Hu Gengshen in 2001. The occurrence of the ecological translation is connected with the social and academic development.

Firstly, starting from 1960s, the human society began to enter the ecological civilization stage. In 1972, the release of the famous environmental declaration in America brought human' attention to environmental protection. China, on its part, also put forward a series of measures to deal with it, such as the strategy of sustainable development. The ecological dimension has been taken in research against such background.

Secondly, it is a corollary of the transformation of modern philosophy. During the 20th century, many philosophers around the world put up with many views where they put the ecological environment in the first place. For example, the famous French philosopher Jacques Derrida put forward the approach that "the center can be in the structure or outside the structure" (Derrida, 1967). This turn has provided translation studies with an ecological perspective to view translation activities.

2 The Main Contents of Eco-translatology

Currently, the eco-translatology contains nine theories. Here the author is going to talk about two of them.

First, adaptation and selection. In the view of eco-translatology, it is the instinct of translators to adapt to the environment and select proper words, phrases in the process of translation. And this is also the essence of translation. In order to produce a better translation work, the translators need to see themselves as a part of nature in order to adapt to it and then select a better version that best fits the environment. In this sense, translation is a process of translator's adaptation and selection.

Secondly, the transformation of three dimension. The three dimensions refer to linguistic, cultural, and communicative dimension. The linguistic dimension requires translator to pay extra attention to language form and change it if necessary. The cultural dimension requires translators to have a good knowledge of two cultures. The communicative dimension needs translator to emphasize the communicative function of language. The employment of the three dimensions will be explained in detail in the following parts.

\section{B. About the Tourist Public Signs}

1 The Definition of Tourist Public Signs

The tourist public signs can be defined from the following ways. Firstly, the tourist public sign is expected to announce something necessary to the public in the tourist public places, such as identifications, marks, posters, bulletins, warnings. Secondly, in public places, tourist public sign with special communicative function can appeal people to obey rules. When tourists see the public signs, they will obey the orders to do what they want to do. Besides, public signs are the direct way to communicate with tourists, which decides whether the tourists have a good time in their travel.

All in all, as a written language during the travel, tourist public signs play an important role in indicating, warning, marking and noticing.

2 Features of Tourist Public Signs

In public places, tourist public sign is a service linguistic mark delivering some information to publics making them to do something or not to do something with the functions of managing, regulating and ensuring in social economic and cultural sides.

In order to make tourists get the meanings that signs represented, the linguistic feature of English tourist public signs are concise and brief. For example, the sign “为了您和大家的健康, 吸烟请到吸烟区” can be translated as “No Smoking" instead. Besides, most of them use directive and omitted sentences, and a large number of nouns, verbs, noun phrases and verb phrases are used in tourist public signs, which are always in present tense. For example, the signs “游 客止步” “危险” “免票入” can be translated as “Staff Only” “Danger” “Admission Free” respectively. What is more, according to professor Lv Hefa, public signs are always indicative, suggestive, restrictive and compulsive, which can be illustrated by the examples “餐饮部”（Food and Beverage）, “售完”（Sold Out）, “左侧行驶”（Keep Left） and “不准随地吐痰”（No Spitting）. These public signs are also very common in tourist attractions.

3 Function of Public Signs

Public signs are widely used in tourist attractions. It undertakes the responsibility of offering information to tourists, which we have talked about in the above. Apart from it, tourist public signs also have the function of setting up a good image for the place and elevating its reputation. For example, “三亚欢迎您!” (Welcome to Sanya!)

\section{Summary}

In this part, the author talked about the background and main contents of eco-translatology, which consists of the cognitive path of relational sequence chain, the ecological features of isomorphism, and the theory of adaptation and selection, and something about the tourist public signs: its definition, features and functions. In the next chapter, we will discuss the translation of tourist public signs in detail. 


\section{A. Samples of Tourist Public Signs and Methods of Collection}

In order to obtain the samples of tourist public signs, the author of this paper, apart from collecting information from the internet, related newspapers and journals, visited a lot of interest of places and kept track of them by taking photos. Here are some examples.

\section{错误示范}

$\begin{array}{ll}\text { 商店 } & \text { Shopping Area } \\ \text { 医疗室 } & \text { Yi Liao Shi } \\ \text { 洗手间 } & \text { Rest room } \\ \text { 开放时间 } & \text { Houre } \\ \text { 不可回收 } & \text { Organism } \\ \text { 餐饮 } & \text { Restaurant } \\ \text { 冲淋区 } & \text { According to Drenching Area } \\ \text { 办公区 } & \text { Office } \\ \text { 严禁烟火 } & \text { No Fire } \\ \text { 小心地滑 } & \text { Slip Carefully } \\ \text { 请勿跨越 } & \text { No Crossing } \\ \text { 无烟景区 } & \text { No Smoking Landscape Area } \\ \text { 当心火灾 } & \text { Warning Fire } \\ \text { 小心头手 } & \text { Take Care of Your Head or Hand } \\ \text { 盐湖养生城 } & \text { Salt Lake City Health }\end{array}$

\author{
正确示范 \\ Stores \\ Clinic \\ Toilet \\ hour \\ Unrecyclable \\ Food \& Drink \\ Shower Area \\ Office Area \\ No Smoking \\ Wet Floor, Caution \\ No Climbing \\ Smoking Free Scenic Spots \\ Danger of Fire \\ Mind your head and hand \\ Health Preserving Center of Salt Lake
}

\section{B. Errors in the Translation of Tourist Public Signs and Causes Analysis}

After the analysis of collected information, the author found that the misuses of tourist public signs are usually caused by the following reasons:

1 Misuses of Linguistic Knowledge

Misspelling is one of the most common errors and is also easily to be ignored in the translation of tourist public signs. These errors can be seen at restaurants and hotels owned by the private who have little professional knowledge about the translation, which is why these errors happened.

For some small business entities, they just use the Chinese pinyin directly instead of translating them carefully. For them, the translation is merely a decoration, without carrying specific information on it.

Translating word by word. For example, “开水间”: Open water room, which is affected by the Chinese thinking.

Grammatical error is another mistake that is hard to find if translators do not have a good knowledge of the grammar. Errors are caused by the misuse of genders (Mr or Ms), form of nouns, misuse of articles (a, an or the), the types of verb. For example, “禁止触摸” : “No touch (touching)”; “男士正装” : “Men’s Suit (Suits)”; “开馆时间” : “Open (Opening) hours”; “退换商品” : “Return (Returns)”; “女士体闲服” : “Woman’s (Women’s) Wear”.

Generally speaking, errors of this type are caused by the inexperience of the translators and lack of inspection from experts and reference of translational standards.

2 The errors caused by misunderstanding to cultures and context

In order to produce a proper translation, one must fully understand the original meaning of public signs. Any misunderstanding to original information will lead to failure. For example, the public sign of “小心碰头”, the translation is "Attention Your Head". The true meaning of the sign is "mind your head". The translation is totally against the meaning in Chinese.

\section{The Translation Strategy under the Guidance of ECO-TRAnSLAtology}

\section{A. Eco-translatology-oriented Solutions}

Ways to solve this problem are diversified. Here the author tries to put up with solutions from the following three aspects.

1 Improving the translator's ability

Being the operator of translation activity, the translators play a critical role in the work translation. It is imperative that the translators should be well-educated and have full ability to master both Chinese and English. So it is necessary to improve the quality of English teaching in higher education. When they graduate, a test need to be held to check if they are qualified. Besides, the translators should also take responsibility and take it seriously.

2 Improving the Public Awareness

Many errors are caused by small business institutions, because they ignore or despise the importance of the public signs. They just think of them as a form, a decoration or a fashion. Only when they change their minds and attach significant importance to the translation of public signs can the situation be improved. So, it is critical to improve the public awareness. 
3 Strengthening Supervision of Government

During the process of improving the quality of public signs translation, the relevant department should perform their duties: They should strengthen their control over it: Any improper translation should be removed. Besides, they should also assign professors in this field to help improve the work.

\section{B. Translation Strategies under the Guidance of Eco-reanslatology}

There are a lot of strategies can be followed to improve the quality of translation. Here the author discusses elaborately two of them.

1 Selective Adaptation

1.1 Selective Adaptation to Target Readers' Needs

Public signs at tourist attraction take the responsibility of reminding the visitors to observe the rules or as an assistant for guiding them better understand what they are supposed to do. Signs like "Park Rules And Regulations(游园须知)" and "Notice (注意事项)" are commonly seen there. For the purpose of emphasizing seriousness and authority, Chinese public signs are prone to employ words like “禁止”, “严禁”, “请勿”. When they are translated into English, words like "forbidden", "prohibit" and "do not" are still used.

Example 1:

Chinese:

1. 禁止排放污水。

2. 禁止在河边垂钧。

3. 景区内禁止鸣笛。

English:

1. Waste water is forbidden to discharge.

2. Fishing on the river is forbidden.

3 . Whistle is not allowed in the scenic spots.

Example 2:

Chinese:

1. 严禁向山下抛扔垃圾。

2. 水深危险, 请勿下水游玩。

3. 殿内禁止拍照。

English:

1. Strictly prohibit throwing garbage downhill.

2. Taking care to deep water, not to take water please.

3. No photo.

Most visitors want to spend a happy time and enjoy themselves at the tourist attractions. If a public sign of compelling function is stated with a weak tone, readers may not take it seriously and ignore it, which may lead to danger. By contrast, if the tone of a translated text is so strong that it makes the target readers feel uncomfortable, it can hardly be a satisfactory translation. Therefore, a suitable mood or tone should be kept in mind in translating in order to adapt to target readers' needs in scenic spots. Besides, westerners stress more on "dos" instead of "don'ts" (Nord, 2001), and more declarative sentence are employed to mitigate the stern tone of voice, so that visitors can enjoy themselves better. Here is the author's version:

Revised version for Example 1:

1. No waste water discharge.

2. No fishing.

3. Horn prohibited.

Revised version for Example 2:

1. No littering.

2. Caution: Deep Water, No Swimming.

3. No photography, please/Cameras off, please.

1.2 Selective Adaptation to the environment of Public Signs

Public signs are placed in the certain environment, namely, signs are meant to communicate with people from all walks of life and changing semantically in line with the surroundings where it is located. This feature requires translators to make appropriate linguistic adaptation which can be adaptable to the translational eco-environment of public signs.

Example 3: 请勿攀爬 Do not climb (next to dangerous gully)

Example 4: 请勿攀爬 NO CLIMBING (in the subway)

Example 5: 请勿攀爬 Do not climb (beneath the tree)

Example 6: 严禁攀爬 (on the fence gate)

These four public signs, which have the same Chinese meaning, are located at different places. The first sign in an amusement park is placed next to a deep gully in order to remind kids not to approach. The second one often can be 
seen in the subway, in a bid to ask people to keep in order. The third sign is fixed beneath a tree, while the fourth one is located at the gate. When you glance at these signs, maybe you think of them as the standard version. They all stress that the behavior of climbing is not allowed because it can be dangerous. Nevertheless, when looked. from the perspective of eco-translatology, these public signs are far from satisfactory. It is so abstract and general that the visitors can hardly comprehend what they are supposed to do.

Revised version for Example 3: Danger! Deep Gully!

Revised version for Example 4: Please keep in order.

Revised version for Example 5: Protect the tree for everyone to enjoy.

Revised version for Example 6: No climbing over.

1.3 Selective Adaption to the Purpose of Source Text

Example 7:

Chinese: 森林防火千秋业，生态安全万代兴

English: Forest fire prevention is a long term project; Ecological security will be long-term benefit of human beings.

Example 8: 危险！请勿靠近 Be aware of the cliff! Do not go ahead any further.

For Example 7, the sign is set up to prevent the occurrence of fire. It is committed to encourage people to protect forest. However, this public sign compresses so much content in such limited space, which may not serve the purpose of the source text, in that target readers are more likely to have a quick glimpse instead of standing still when they pass by these public signs. In other words, readers are prone to finishing reading and understanding the sign within a short time. Therefore, in order to achieve the function of the public sign, the first thing is to be concise. Those that are fully occupied or redundant can hardly arouse passerby's response. The same problem exists in Example 8. For this reason, the two examples can be revised as following:

Revised version for Example 7:

Please protect the forest for generations' welfare.

Revised version for Example 8:

Danger! No approaching! Cliff!

2 Adaptive Selection

According to eco-translatology, the high-quality translation works must be those that highly integrate selective adaptation with adaptive selection during translating. This part is concentrated on translation as selection from the perspective of the three principal dimensions - linguistics, culture and communication.

2.1 Adaptive Selections in Linguistic Dimension

Adaptive selection in linguistic dimension emphasizes the conversion and selection of language forms. In other words, it gives great priority to the choice of words, phrases and sentences.

Example 9: 残疾人通道 Access for Disabled People

Example 10: 无障碍通道 Wheel chair ramp

Example 11: 无障碍坡道 Accessible Ramp

Example 12: 无障碍卫生间 Disabled Toilet

According to Oxford Advanced Learner's English-Chinese Dictionary, “for" is used to show purpose or function. In the above examples, signs used in the washroom or sports venues are in a bid to convey the message that this passage or facilities are specially designed for the disabled person for the purpose of their convenience. The proposition "for" makes theses phrases more relevant and comprehensible. Referring to the above Example 10“无障碍通道”, it is also reasonable for us to render it into "Access for wheel chair"; for Example 11, "Ramp for Disabled Person"; for Example12, "Facilities for Disabled People".

Example 13:

Chinese: 芳草萋萋,踏之何忍。

English: The grass is fragile. How hardhearted to trample them?

This public sign can be seen everywhere. By contrast, the readers can find that the target text is completely literal translation. Evidently, the translator ignores the different features of Chinese and English sentence structure. Chinese focuses on meaning, while English emphasizes structure. This translated version makes no sense to westerners, let alone accomplishing its function.

Revised version for Example 13:

Please keep off the grass.

2.2 Adaptive Selections in Cultural Dimension

Adaptive selection in cultural dimension concerns much about cultural interpretation and transference in two languages. In other words, the translator is supposed to tackle differences between cultural background information such as readers' beliefs, moralities and values.

Example 14: 做一名文明乘客, 今天你有序排队了吗?

Example 15: 文明参观 Civilized Visiting

Example 16: 废物不乱扔 举止显文明

Do not throw things randomly. Be civilized. 
There's something in common in the above examples. They all contain the word “文明”. It is unreasonable to translate them as “civilized" without serious consideration. In fact, the words “文明” mean to be well-educated or courtesy in Chinese. It refers to a kind of good conduct. However, in English culture, "civilized" is the antonym of “uncivilized(野蛮的)". Obviously, it makes no sense if it is translated as "civilized". Hence the adaptive selection is necessary for translator according to distinguished values. Combining with the principle of "conciseness", the author gives suggested texts for these signs.

Suggested version for Example 14:

Be polite and stand in line, please.

Suggested version for Example 15: Be a polite visitor.

Suggested version for Example 16:

No littering. Courtesy is within your polite manner.

2.3 Adaptive Selections in communicative Dimension

Example 17: 请勿摘花

Version 1: Don't pick the flowers

Version 2: Leave the flowers for everyone to enjoy

Version 3: I greet you with smile, you behave with style

Adaptive selection in communicative dimension put great emphasis on practical communicative function. In the above examples, the sign “请勿摘花” in Chinese can be translated into three versions. They are "Don't pluck the flowers", "Leave the flowers for everyone to enjoy", and "I greet you with smile, you behave with style" respectively. The first text is an imperative sentence with a harsh tone; the second one is in a milder mood, indicating the objective or reason of protecting the flowers; the third version using personification appears to be vivacious and genial, which are more apt to activate readers' sense of pity towards flowers. As far as linguistics and culture are concerned, the three versions are all reasonable. Which version is best depends on the environment where it is placed. The translator needs to make a prudent selection to achieve its communicative function.

\section{CONCLUSION}

This paper demonstrates the translation of public signs from two angles: selective adaptation and adaptive selection, in a bid to produce a better and highly effective translation of public signs in scenic spots under the guidance of eco-translatology. It also helps readers to get a deeper understanding of the nature, the process, principles and strategies of translating tourist public signs.

The contrastive and descriptive analyses of these cases bring about the following conclusions. Firstly, in order to produce a high-quality translation work, the translator must adapt to tourists' needs, the environment and the purpose of source text. Secondly, as for adaptive selection, the translator must conform to the three principal dimensions-linguistics, culture and communication. In a nutshell, it requires the translator not only to have a good command of knowledge of two languages, but also two cultures.

However, there are still a lot of flaws. Firstly, a great number of Chinese public signs do not have their counterparts in English because Chinese and English pertain to different linguistic school. Secondly, due to the limitation of the author's ability, some of the examples given in the paper may have a better version for them. A lot of things need to be done to improve the situation.

\section{ACKNOWLEDGMENTS}

This paper is excerpted from my academic thesis, and I would like to express my gratitude to all of my teachers for their help and guidance, especially to my adviser Wang xiaomei. Without her help, I would not finish the paper smoothly. She gave me much advice and I benefit a lot. I will never forget all of those. And I want to thank my parents for their supporting and selfless care. All in all, I can't make it without those people. I will keep my passion for studies and make much progress in the future.

\section{REFERENCES}

[1] Cenoz, J. \& Gorter, D. (2006). Linguistic Landscape and Minority Languages. The International Journal of Multilingualism, (3):35-37.

[2] Derrida, J. (1967). La Voixet Le Phenomene. Paris: PUF.

[3] Duan, L. C. (1990). Appeal: Ask Your Colleagues in The Translation Community to Care about Publicity. Chinese Translator Journal, (5):2-10.

[4] Firth, J. R. (2000). The Treatment of Language in General Linguistics. London: The Medial Press.

[5] Ge, R. S. (2010). On the Translation of Public signs into English and its Strategies from the Perspective of German functional Translation. Journal of Tibet University for Nationalities, (4): 102-104.

[6] Guo, X. D. (2011). On the Translation of Public Signs from the View of Communicative Translation Theory. Overseas English, (2): $142-143$.

[7] He, X. T. (2006). The Present Situation of C-E Public Sign Translation and its Communicative Translation Strategies. Foreign 
Languages and Their Teaching, (3): 37- 40.

[8] He, Z. R. (1997). Pragmatics and English Learning. Shanghai: Shanghai Foreign Languages Press.

[9] Hou, X. J. (2011). On the Translation of Prohibited Public Signs from the Politeness Principle. Journal of Lanzhou Institute of Education, (4): 146-148.

[10] Hu, G. K. (2004). An Approach to Translation as Adaptation and Selection. Wuhan: Hubei Education Press.

[11] Katan, D. (1999). Translating Cultures. Manchester: St. Jerome Publishing.

[12] Landry, R \& Bourhis, R. (1997). Linguistic Landscape and Ethnolinguistic Vitality: An Empirical Study. Journal of Language and Social Psychology, (16): 23-27.

[13] Lv, H. F. (2004). C-E Translation of Public Signs. Chinese Translation of Science and Technology, (2): 25-27.

[14] Munday, J. (2001). Introducing Translation Studies. London: Routledge.

[15] Mary Snell-Hornby. (2001). Translation Studies: An Integrated Approach[J]. Shanghai Foreign Language Education Press, (2):71-74.

[16] Ni, C. B. \& Liu, Z. (1998). The Principles of Translating Markedness into English and an Analysis of Examples. Shanghai Science and Technology Translation, (2):56-58.

[17] Nord, C. (2001). Translating as a Purposeful Activity. Shanghai: Shanghai Foreign Language Education Press.

[18] Shu, H. J. (2010). A Study on the Translation of Public Signs from the Perspective of Ecological Translation--Taking the Theme Slogan of Shanghai World Expo as an Example. Shanghai Journal of Translator, (2): 39-42.

[19] Sr. Anwar AL-thway. (2008). Linguistic Landscape in Yemen. Yemen Times.

[20] Thomas, J. (1983). Cross-cultural Pragmatic Failure. Applied linguistics, (4): 91- 112.

[21] Wang, M. H. (2011). Translation of Public Signs of Ttourist Attractions under the Guidance of Skopos: A Case Study of Qinhuangdao City, Hebei Provinc. China off-campus Education Magazine, (9):50-53.

[22] Wang, L. Y. (2011). English Translation of Public signs from an Aesthetic Perspective. Journal of Chifeng College, (9): 188-190.

[23] Wang, Y. \& Lv, H. F. (2007). C-E translation of public sign. Beijng: China Foreign Translation and Publishing Corporation.

[24] Wang, Y. C. (2009). Readers Attention to the C-E Translation of Public Signs in Communicative Translation Theory. Journal of Xiamen University of Technology, (3): 103-106.

Yayan Yu was born in Linfen, China in 1992. She received her bachelor's degree in English teaching from Yuncheng University, China in 2016.

She is currently an assistant in Modern College of Humanities and Sciences of Shanxi Normal University, Linfen, China. Her research interests include English teaching and linguistics.

Ms.Yu got a second prize scholarship and a prize of excellent student during the study for a master degree. 